\title{
Effect of Compost and Gypsum Application on Yield and its Attributes of Three Bread Wheat Cultivars As Well As Soil Properties under Two Irrigation Levels \\ "El-Sayed, M.E.A. ${ }^{1}$ and G.M.M. Soliman ${ }^{2}$
}

${ }^{1}$ Soils, Water and Environmental Research Institute, Agriculture Research Center, Egypt.

${ }^{2}$ Field Crops Research Institute, Agriculture Research Center, Egypt.

*Email: eid1592003@yahoo.com

Received on: $29 / 12 / 2019$

Accepted for publication on: 18/2/2020

\begin{abstract}
:
Many of soil amendments can be used to reduce the effect of saline-sodic soils on crop production. Accordingly, the main goal of the present study is to evaluate the salt tolerance, growth and yield performance of three wheat cultivars (Shandaweel 1, Sids 1 and Sids 14) to salt stress in Egypt. This research was carried out in a field experiment at the Shandaweel Agricultural Research Station during the two successive growing seasons 2017/2018 and 2018/2019 using Randomized complete block design using strip blot arrangement with three replications where, two irrigation levels $\left(\mathrm{I}_{1}: 100 \%\right.$ and $\mathrm{I}_{2}: 120 \%$ of field capacity) were allocated in split blocks, four compost and gypsum treatments; control: without application, compost (4 ton/feddan), gypsum( 8 ton/feddan) and compost + gypsum) were assigned to the sub plots and three wheat cultivars were allocated in the sub sub plots. The results showed that there is a significant difference between tested wheat cultivars for all studied traits. The irrigation by $120 \%$ FC gave the highest significant mean values of all studied traits in both seasons except for number of kernels/spike in the first season. For wheat cultivars, there were highly significant differences for all the studied traits between the studied bread wheat cultivars. Treatment by compost or/and gypsum had significant effect in all the studied traits in both seasons as compared to control treatment. Moreover, the irrigation by $120 \% \mathrm{FC}$ in the presence of compost and gypsum enhanced soil properties and reduced the salinity effect.
\end{abstract}

Keywords: Gypsum, compost, wheat, irrigation levels, soil properties.

\section{Introduction:}

Wheat, is the most important crop for human consumption in the world, as strategic crop and plays a great role in terms of economy (Jahan et al., 2019 and Barutcular et al., 2017). It is the staple food for a large part of world population. Moreover, wheat is the major widely grown species across the globe and feeds more than one - third of the global population (Shahzad et al., 2013), while, food production is limited by saline soils in arid and semi-arid regions of the world (Rengasamy, 2010). Soil salinity is one of the major abiotic stresses affecting agricultural production in semi-arid regions and has negative impacts on plant growth and global crop productivity (Huang et al., 2008 and Attia and El-Araby, 2017). Therefore, breeding for realizing salt tolerance would be an effective mean for improving yield and yield stability under such conditions (Genc et al., 2007). 
In Egypt the cultivated area is about 7.2 million feddans, the area of salt-affected soils has been estimated to be about 1.9 million feddans (Abdel-Fattah and Merwad, 2016). In 2017, the cultivated wheat estimate area was 3.1 million feddans and production was 8.8 million tons (FAO/LPNWS 2018). Increasing wheat production is a national target in Egypt to fill the gap between wheat consumption and production. However, the production of wheat is influenced by various biotic and abiotic stresses, which led to changes in growth and yield of plants (Abdelaal et al., 2018). Salinity and water stress are the major abiotic stresses that adversely affect crop productivity and quality of plants (Chinnusamy et al., 2005 and Borlu et al., 2018).

Adding gypsum is the most common amendment used to overcome soil sodicity hazards due to its low cost, availability, and ease of handling (Siyal et al., 2002). The application of gypsum also decreased $\mathrm{pH}$, electrical conductivity (EC), exchangeable sodium percentage (ESP), and bulk density (Manzoor et al., 2001). Composts, has been effectively used to improve salt affected soils (Feizi et al., 2010). The addition of gypsum increased soil hydraulic conductivity and infiltration rate (Abdel-Fattah, 2011). Sorour et al., (2019) stated that irrigation with water amount equal to 110 or $120 \% \mathrm{FC}$, $100 \%$ gypsum requirements and 7.5 compost and $45 \mathrm{~kg} \mathrm{~N}$ fed-1 was the best treatment for getting high grain yield, improving the soil chemical properties, nutrients availability and increasing the water productivity of salt-affected soil. Yassin et al.,
(2019) reported that the effect of soil salinity was highly significant for days to heading, days to maturity, plant height, number of spikes, biological yield, number of kernels/spike and grain yield. Wheat cultivars responded differently either within the same, or among, the salinity levels for all studied traits except number of grains/spike (Gadallah et al., 2017).

The object of this study was to investigate the effect of saline-sodic soil on the studied wheat cultivars production under different treatments irrigation levels $\left(\mathrm{I}_{1}: 100 \%\right.$ and $\mathrm{I}_{2}$ : $120 \%$ of field capacity as leaching treatment), gypsum and compost.

\section{Materials and Methods}

The present study was carried out at the Experimental Farm of Shandaweel Agricultural Research Station, Agricultural Research Center (ARC), Egypt, during the two successive growing seasons of 2017/2018 and $2018 / 2019$ to study the effect of irrigation levels and assessing the role of compost and gypsum on yield and its attributes of wheat cultivars and soil physical properties. The experiment was laid out in RCBD using strip blot arrangement with three replications with a plot size of $2 \times 3 \mathrm{~m}^{2}$ where, two irrigation levels were applied $\left(\mathrm{I}_{1}: 100 \%\right.$ of field capacity and $\mathrm{I}_{2}: 120 \%$ of field capacity (leaching treatment)) were allocated in the main plots, four compost and gypsum treatments (control, 4 ton compost/ feddan, 8 ton gypsum / feddan and compost + gypsum) were assigned to the sub plots and applied at preparing soil to sowing and three wheat cultivars (Shandaweel 1, Sids 1 and Sids 14) were allocated in the sub sub plots. Planting was done on $25^{\text {th }}$ No- 
vember in both seasons. All the required agronomic practices were followed uniformly in all plots throughout the growing period. During the two seasons of study the following data were recorded on whole the experimental units: days to heading (DH), days to maturity (DM), plant height $(\mathrm{cm}$.$) , number of spikes / \mathrm{m}^{2}$ (No. of spikes $/ \mathrm{m}^{2}$ ), biological yield (BY, ton/fed), 1000-kenel weight $(1000-K W, g$.$) , number of ker-$ nels/spike(No. of kernels/spike) and grain yield (GY, ard/fed).

\section{Soil Analysis:}

Some physical and chemical properties of soil were determined after soil preparation and before fertilization. Soil samples were taken from the experimental site $(0-30 \mathrm{~cm}$ depth) representing the different treatments after harvest time. The samples were air-dried and passed through $2 \mathrm{~mm}$ sieve pores. Particle size distribution was determined by the pipette method (Gee and Orr, 1994). The organic carbon (OC\%) was analyzed by Walkey and Black procedure (Nelson and Somners, 1982). The $\mathrm{pH}$ was determined in soil/water suspension $(1: 2.5)$ according to Jackson (1973). The EC, major cations and anions were measured in the soil paste while $\mathrm{CaCO} 3$ was determined using the calcimeter method according to Black (1965). Saturation percentage (SP), bulk density (BD), field capacity (FC), wilting point (WP) and available water (AW) were determined as described by Hesse (1971).

\section{Statistical analysis:}

All data were analyzed using MSTAT-C computer software package. The differences among treatment means were compared using the least significant differences test (LSD 0.05 ) according to Gomez and Gomez (1984).

\section{Results and Discussions \\ 1- Soil Properties}

The soil had a clay loam texture (38.9\% clay, $35.8 \%$ silt, and $25.3 \%$ sand), low in organic matter and contained $9 \% \mathrm{CaCO}_{3}$. The chemical properties of the soil under study are presented in Table 1. In accordance with the guidelines of the US Salinity Laboratory (1954), the soil was classified as saline-sodic as (i) the EC of its saturation extract was $14.54 \mathrm{mS}$ $\mathrm{cm}^{-1}$; (ii) ESP was $44.9 \%$; and (iii) $\mathrm{pH}$ was 8.1. This may be attributed to the extremely high soluble $\mathrm{Mg}^{2+}$ and $\mathrm{Na}^{+}$contents. Soluble sodium was the dominant cation, constituting approximately half of the soluble cations while chloride was the major anion. Cations found, listed in the order of decreasing propotion, were $\mathrm{Na}^{+}>\mathrm{Mg}^{2+}>\mathrm{Ca}^{2+}>\mathrm{K}^{+}$.

Results indicate that all the used amendments either, singly or in combination showed a pronounced decrease in soil salinity indicators EC and $\mathrm{pH}$, especially with leaching treatment $\left(\mathrm{I}_{2}\right)$ in two seasons (Table 1). However, the results show a slightly lower soil $\mathrm{pH}$ among treatments, this may be explained by the soil had the high buffering capacity due to the clay loam texture.

The changes in the EC of leachate during leaching of the untreated and treated saline-sodic soil are shown in Table 1. Generally, results show that a very sharp decrease in EC values for all treatments, particularly at the beginning period of the leaching process $\left(\mathrm{I}_{2}\right)$. Soluble salts re- 
moved in leachates depended on the number of leaching carried out $\left(\mathrm{I}_{2}\right)$. A sharp decreased in occurred at the beginning period of the leaching process means a greater portion of salts were removed. Also, the lower EC values were found in untreated soil (control), particularly at the beginning of the leaching process. Leaching the soil treated with gypsum was more effective in removing the total soluble salts (TSS).

Leaching with compost did not create a sodification hazard and ESP obtained values at the end of leaching were lower than the control. As expected, increasing gypsum rates decreased ESP. Moreover, a high degree of soil improvement was realized when leaching began with gypsum + compost and ESP value was decreased.

Soil organic matter encourages granulation, increases cation exchange capacity (CEC) and is respon- sible for up to $90 \%$ adsorbing power of the soils. Cations such as $\mathrm{Ca}^{2+}$, $\mathrm{Mg}^{2+}$ and $\mathrm{K}^{+}$are produced during decomposition (Brady and Weil, 2005). Organic amendments decreased soil sodicity and increased exchangeable $\mathrm{Ca}^{2+}$ and $\mathrm{Mg}^{2+}$. Consequently, concerning compost, the decreases in soil-pH in soil this illustrates the indirect effect of decreased sodium and the direct effect of organic acids, which must have been formed during decomposition of compost and applying organic composts to saline sodic soils would help in collating calcium and decreasing soil $\mathrm{pH}$ leading to an increase in solubility of $\mathrm{CaCO}_{3}$ (Çelik et al., 2008). The application of gypsum decreases the $\mathrm{pH}$, electrical conductivity (EC), exchangeable sodium percentage (ESP), and bulk density and increases the hydraulic conductivity and infiltration rate (AbdelFattah, 2015). 
Table 1. Chemical properties of the soil under study (seasons 2017/2018 and 2018/2019).

\begin{tabular}{|c|c|c|c|c|c|c|c|c|c|c|c|c|c|c|c|c|c|}
\hline \multirow{2}{*}{ 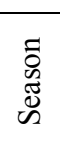 } & \multirow{2}{*}{ : } & & \multirow[b]{2}{*}{ 焉总 } & \multirow{2}{*}{\multicolumn{2}{|c|}{ 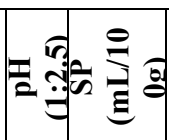 }} & \multirow[b]{2}{*}{$\sum_{0}^{\partial}$} & \multirow[b]{2}{*}{ 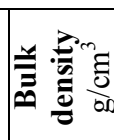 } & \multirow[b]{2}{*}{ II } & \multirow[b]{2}{*}{ 诖 } & \multicolumn{4}{|c|}{ Cations me/L } & \multicolumn{4}{|c|}{ Anions me/L } \\
\hline & & & & & & & & & & $\mathrm{Ca}^{2+}$ & $\mathbf{M g}^{2+}$ & $\mathrm{Na}^{+}$ & $\mathbf{K}^{+}$ & 8i & 10 & $\mathrm{Cl}^{-}$ & $\mathscr{D}^{+} \dot{1}$ \\
\hline \multirow{11}{*}{ 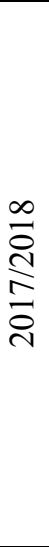 } & 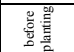 & & & 8.1 & 56 & 1.22 & 1.42 & 29.4 & 14.5 & 12.1 & 59.5 & 65.1 & 8.1 & - & 52.3 & 55.6 & 36.4 \\
\hline & \multirow{10}{*}{ 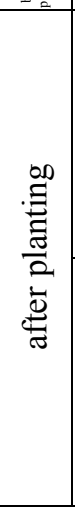 } & \multirow{5}{*}{$I_{1}$} & control & 8.1 & 56 & 1.1 & 1.44 & 29.3 & 14.8 & 12.2 & 60.7 & 67.2 & 8.2 & - & 55.2 & 57.7 & 37.5 \\
\hline & & & compost & 7.9 & 58 & 1.7 & 1.41 & 29.3 & 12.9 & 11.1 & 5.8 & 60.6 & 7.3 & - & 50.3 & 2.4 & 35.6 \\
\hline & & & gypsum & 7.9 & 55 & 1.1 & 1.41 & 29.2 & 11.7 & 12.9 & 50.2 & 54.2 & 6.2 & - & 46.7 & 49.5 & 33.3 \\
\hline & & & $\begin{array}{l}\text { compost }+ \\
\text { gypsum }\end{array}$ & 7.8 & 56 & 1.74 & 1.40 & 29.1 & 10.1 & 13 & 45.6 & 47.1 & 5.7 & - & 43.3 & 45.2 & 29.1 \\
\hline & & & F test & ns & $\mathrm{ns}$ & $\mathrm{ns}$ & ns & $\mathrm{ns}$ & * & * & $*$ & *** & * & - & * & *** & ** \\
\hline & & \multirow{5}{*}{$\mathrm{I}_{2}$} & control & 8.0 & 55 & 1.00 & 1.42 & 29.3 & 13 & 11.9 & 55 & 60.1 & 7.6 & 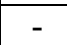 & 53.1 & 54.1 & 35.2 \\
\hline & & & compost & 7.8 & 56 & 1.7 & 1.40 & 29.4 & 11.1 & 11 & 51.4 & 52.3 & 7.1 & - & 46.2 & 47 & 31.2 \\
\hline & & & gypsum & 7.9 & 55 & 1.2 & 1.41 & 29.3 & 10.5 & 12.8 & 50 & 47.5 & 6.1 & - & 41.2 & 44.3 & 28.9 \\
\hline & & & $\begin{array}{c}\text { compost+ } \\
\text { gypsum }\end{array}$ & 7.8 & 55 & 1.8 & 1.39 & 29.4 & 9.5 & 13.1 & 43.2 & 40.8 & 5.4 & - & 40 & 42.2 & 26 \\
\hline & & & F test & ns & ns & ns & $\mathrm{ns}$ & $\mathrm{ns}$ & * & * & * & $* *$ & ** & - & * & $* *$ & * \\
\hline \multirow{11}{*}{ 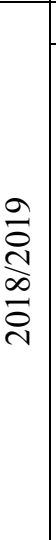 } & 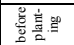 & & & 8.0 & 55 & 1.31 & 1.40 & 29.4 & 11.9 & 12.9 & \begin{tabular}{|l|}
47.5 \\
\end{tabular} & 50.1 & 7.3 & - & 44.3 & 46.6 & 29.4 \\
\hline & \multirow{10}{*}{ 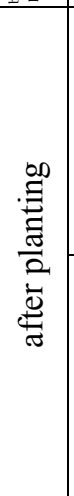 } & \multirow{5}{*}{$\mathrm{I}_{1}$} & control & 8.1 & 54 & \begin{tabular}{|l|}
0.9 \\
\end{tabular} & 1.42 & 29.3 & 12.8 & 12.3 & \begin{tabular}{|l|}
49.2 \\
\end{tabular} & 53.1 & 7.9 & - & 46.2 & 49.7 & 34.5 \\
\hline & & & compost & 7.8 & 58 & 1.75 & 1.40 & 29.3 & 10.9 & 11.1 & 43.7 & 48.3 & 7 & - & 40.1 & 43.4 & 29.2 \\
\hline & & & gypsum & 7.9 & 55 & 1.25 & 1.40 & 29.2 & 9.7 & 11.9 & 40.2 & 43 & 6.1 & - & 38.7 & 39.5 & 24.3 \\
\hline & & & $\begin{array}{c}\text { compost+ } \\
\text { gypsum }\end{array}$ & 7.8 & 56 & 1.84 & 1.39 & 29.1 & 9.1 & 12.2 & 36.6 & 38 & 5.2 & - & 32.3 & 33.5 & 22.1 \\
\hline & & & F test & ns & $\mathrm{ns}$ & $\mathrm{ns}$ & ns & ns & * & * & * & $* *$ & $*$ & - & * & $* *$ & $* *$ \\
\hline & & \multirow{5}{*}{$\mathrm{I}_{2}$} & control & \begin{tabular}{|l|}
7.9 \\
\end{tabular} & 55 & 1.00 & 1.41 & 29.3 & 12 & 10.9 & 45 & 49.8 & 7.1 & - & 41.1 & 43.1 & 32.1 \\
\hline & & & compost & 7.8 & 56 & \begin{tabular}{|l|}
1.7 \\
\end{tabular} & 1.39 & 29.4 & 9.9 & 9 & \begin{tabular}{|l|}
39.9 \\
\end{tabular} & 44.5 & 6.4 & - & 35.1 & 39.9 & 26.7 \\
\hline & & & gypsum & 7.9 & 55 & 1.2 & 1.40 & 29.4 & 8.5 & 11.8 & 37 & 39.9 & 5.9 & - & 33.2 & 34.2 & 21.3 \\
\hline & & & $\begin{array}{c}\text { compost }+ \\
\text { gypsum }\end{array}$ & 7.7 & 56 & 1.8 & 1.38 & 29.4 & 7.5 & 12 & 33.2 & 36 & 4.9 & - & 29.5 & 30.1 & 19.1 \\
\hline & & & $\mathrm{F}$ test & $\mathrm{ns}$ & $\mathrm{ns}$ & ns & $\mathrm{ns}$ & ns & $*$ & * & * & $* *$ & ** & - & * & $* *$ & * \\
\hline
\end{tabular}

$\mathrm{I}_{1}: 100 \%$ of field capacity and $\mathrm{I}_{2}: 120 \%$ of field capacity ns: non-significant.

* and **: significant at 0.05 and 0.01 levels of probability, respectively.

The decrease in soil $\mathrm{pH}$ due to gypsum application was probably due to a combination of more than one factor, mainly the replacement of sodium by calcium and the formation of neutral salts with $\mathrm{SO}_{4}{ }^{-2}$. The decrease in soil $\mathrm{pH}$ may have been a decrease in sodium concentration as a fraction of the cations. This decreasing may be due to removal of exchangeable sodium from the soil column. Moreover, gypsum solubility is also enhanced because of the increased activity coefficient of calcium and sulfate as a result of increased ionic strength of the solution and the formation of the sodium sulfate ion pair. Besides, large quantities of $\mathrm{CO}_{2}$ must have been evolved during leaching process, some of which would become soluble in soil solution giving carbonic acids.

Data in Table 1 reveal that the concentrations of $\mathrm{Na}$ significantly decreased due to the effect of the leaching process with or without the addition of amendments. The combination between leaching process and all soil amendments has a highly significant effect on the sodium concentration.

Thus, the results of the study indicated that the used amendments either, singly or in combination showed a pronounced decreased in $\mathrm{EC}, \mathrm{pH}$, sodium concentration, and ESP com- 
pared with control treatment. The results showed that combined treatments were more efficient than the single one. Increasing the rate of gypsum used leads to an increase in decreasing salinity as well as sodicity. Thence, the soil properties enhanced which led it to positive effect on crop production.

\section{2- Effect of irrigation levels treat- ments:}

Results in Table 2 clear that the irrigation by $120 \%$ of field capacity gave the highest significant mean values for all the studied traits in both seasons except for number of kernels/spike in the first season. $120 \%$ of field capacity increased days to heading by 2.41 and $3.02 \%$, days to maturity by 2.42 and $3.64 \%$, plant height by 4.07 and $3.80 \%$, number of spikes $/ \mathrm{m}^{2}$ by 10.15 and $7.39 \%$, biological yield by 13.56 and $15.56 \%, 1000$-kernel weight by 9.13 and $7.67 \%$, number of kernels/spike by 1.52 and $10.71 \%$ and grain yield by 11.08 and $12.91 \%$ in the first and second season, respectively. The experiments were repeated across two seasons to give greater reliability to the results. Growth and yield reduction could explained to the inhibitory effect of the osmotic effects of salt in the soil solutions, that causes acting to induce the acceleration senescence due to the leaf water deficit or hormonal disruption from rooting system (Dura et al., 2011). Acevedo, (1991) stated that nun washing treatment which reduced the yield and yield attributes of wheat could be to decrease cell growth, leaf area and partial stomata closure due to the low content of soil water, which decreased the intake of $\mathrm{CO}_{2}$ with consequent decrease of photo- synthesis per unit area. Ashraf and Harris, (2005) found that the salinity caused $20 \%$ lose in potential yield. El-Hendawy et al., (2005) stated that the influence of salinity on the number of spikes and number kernels/spike during early growth stages has a greater impact on final grain yield than on yield components in the last stages. Turki et al., (2012) reported that the decrease in grain yield might be caused by the salinity, which induced reduction of photosynthetic capacity leading to less starch synthesis and accumulation in the grain. Attia and El-Araby, (2017) found that increasing salinity levels caused a significant effect on plant height, number of spikes and grain yield. Gadallah et al., (2017) stated that increased the salinity levels significantly decreased each of days to heading, plant height, number of spikes, number of kernels/spike, 1000-kernel weight and grain yield. Ouhaddach et al., (2018) found that salinity significantly decreased plant height, fresh weight and dry weight. Sorour et al., (2019) reported that grain yield was increased significantly by increasing the irrigation level from 100 to $120 \%$ of field capacity in both seasons.

\section{3- Effect of compost and gypsum treatments:}

Data presented in Table 2 reveal that compost or/and gypsum treatments significantly increased all studied traits in both seasons as compared to control treatment. The highest mean values of days to heading (101 and 111 day), days to maturity (147 and 158 day), plant height (119 and $129 \mathrm{~cm})$, number of spikes $/ \mathrm{m}^{2}(483$ and 548 spike), biological yield 
(10.42 and 10.93 ton), 1000-kernel weight (41.54 and $45.34 \mathrm{~g})$,number of kernels/spike (43.3 and 37.3 spike) and grain yield $(22.20$ and 23.28 $\operatorname{ard} /$ fed.) in the first and second season, respectively, were obtained from plots which treated by both of compost and gypsum. While the lowest mean values of days to heading (95 and 107 day), days to maturity (141 and 151 day), plant height (111 and $122 \mathrm{~cm})$, number of spikes $/ \mathrm{m}^{2}(431$ and 493 spike), biological yield (7.57 and 7.87 ton), 1000-kernel weight (36.17 and $40.29 \mathrm{~g}$ ),number of kernels/spike (40.4 and 32.2 spike) and grain yield (18.24 and 19.04 $\operatorname{ard} /$ fed.)were recorded with the control treatment in the first and second season, respectively. Also, the treatment of compost or gypsum alone significantly increased all the studied traits as compared to control treatment. However, there was a significant differences between these treatments for days to heading, plant height, biological yield and grain yield in the first season and for days to maturity, number of spikes $/ \mathrm{m}^{2}$, biological yield and number of kernels/spike in the second season. These results indicate the role of compost and gypsum in alleviating the adverse effects of salinity stress and results in a significant increment of growth, yield and its components. The soil application of gypsum or compost significantly increased each of plant height, biological yield, grain yield and 1000-kernel weight compared to the control (without application), the highest percentage increase in 1000 grains was recorded from the treatment of gypsum, (Abdel-Fattah and Merwad, 2016). Soils reclaimed with compost gave higher values of straw and grains than the values under application of gypsum under different treatments, this result could be due to the high nutrient content and the low $\mathrm{C} / \mathrm{N}$ rates in compost, Palm et al., (2001). Sorour et al., (2019) reported that add gypsum and compost significantly increased grain yield in both seasons. These results are in agreement with those obtained by Türkmen et al., (2004), Celik et al., (2008).

\section{4- Effect of wheat cultivars:}

Results in Table 2 showed that there is a significant difference between wheat cultivars for all studied traits in the two growing seasons, this indicated differential response of genotypes to salinity for grain yield and the other traits. Shandaweell had the shortest heading duration (96 and 108 day), greatest number of kernels/spike (45.6 and 39.3 kernel) and highest grain yield (21.09 and 22.78 ard.) in the first and second season, respectively. For days to maturity Sids 1 gave the shortest maturity duration 144 days in the first season, while Shandaweell gave the shortest maturity duration (154 days in the second season). For the number of spikes, Sids 1 gave the highest number of spikes 468 spike in the first season, while Shandaweel 1 and Sids 14 gave the highest number of spikes 532 spike in the second season. Sids 14 gave the tallest plants with mean values of 120 and $130 \mathrm{~cm}$ and the heaviest biological yield with mean values of (9.58 and 10.05 ton) in the first and second seasons, respectively. Sids 1 gave the heaviest 1000-kernel weight with mean values of 41.66 and $45.78 \mathrm{~g}$ in the first and second seasons, respectively, while this cultivar 
gave the lowest mean values of biological yield (9.06 and 9.18 ton) and grain yield (19.82 and 20.06 ard.) in the two respective seasons,. Attia and El-Araby, (2017) reported that sids 1 is more than tolerant to salinity than Shandaweel 1. The differences between wheat cultivars could be due to their genetic constitutions and their interaction with the environmental factors prevailing during development. Yassin et al., (2019) stated that there are highly significant differ- ences among the wheat genotypes for all the studies traits in the two seasons. Gadallah et al., (2017) stated that increased the salinity levels decreased significantly each of days to heading, plant height, number of spikes, number of kernels/spike, 1000-kernel weight and grain yield, also they reported that sids 1 and Shandaweell are considered as moderate intolerance to salinity (salinity susceptibility index 0.92 and 0.93 , respectively).

Table 2. Means of the studied traits of wheat cultivars as affected by irrigation levels, compost and gypsum treatments in $2017 / 2018$ and 2018/2019 seasons.

\begin{tabular}{|c|c|c|c|c|c|c|c|c|c|}
\hline 㐘 & Item & \begin{tabular}{|l|} 
Days to \\
Heading
\end{tabular} & $\begin{array}{l}\text { Days to } \\
\text { maturity }\end{array}$ & $\begin{array}{c}\text { Pant } \\
\text { height } \mathrm{cm} .\end{array}$ & $\begin{array}{c}\text { No. of } \\
\text { spikes/ } \mathbf{m} 2\end{array}$ & $\begin{array}{c}\text { Biological } \\
\text { yield (ton/fed) }\end{array}$ & \begin{tabular}{|c|}
$\begin{array}{c}\text { 1000-kernel } \\
\text { weight }\end{array}$ \\
\end{tabular} & \begin{tabular}{|c|}
$\begin{array}{c}\text { No. of kernels/ } \\
\text { spike }\end{array}$ \\
\end{tabular} & $\begin{array}{c}\text { Grain yield } \\
(\text { ard/fed) }\end{array}$ \\
\hline \multicolumn{10}{|c|}{ Irrigation levels } \\
\hline \multirow{4}{*}{ 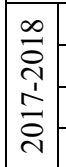 } & $\mathrm{I}_{1}$ & 97 & 143 & 113 & 435 & 8.59 & 37.91 & 41.7 & 19.45 \\
\hline & $\mathrm{I}_{2}$ & 100 & 146 & 118 & 485 & 9.93 & 41.71 & 42.3 & 21.87 \\
\hline & Increasing $\%$ & 2.41 & 2.42 & 4.07 & 10.15 & 13.56 & 9.13 & 1.52 & 11.08 \\
\hline & F test & $*$ & $* *$ & $*$ & $* *$ & $* *$ & $*$ & ns & $* *$ \\
\hline \multirow{4}{*}{ 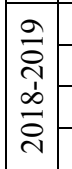 } & $\mathrm{I}_{1}$ & 108 & 152 & 123 & 506 & 8.87 & 41.84 & 33.3 & 20.13 \\
\hline & $\mathrm{I}_{2}$ & 112 & 158 & 128 & 546 & 10.51 & 45.32 & 37.3 & 23.12 \\
\hline & Increasing $\%$ & 3.02 & 3.64 & 3.80 & 7.39 & 15.56 & 7.67 & 10.71 & 12.91 \\
\hline & F test & $*$ & $*$ & $*$ & $* *$ & $* *$ & $*$ & $* *$ & $* *$ \\
\hline \multicolumn{10}{|c|}{ Compost and Gypsum treatments } \\
\hline \multirow{4}{*}{ 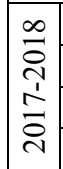 } & Control & 95 & 141 & 111 & 431 & 7.57 & 36.17 & 40.4 & 18.24 \\
\hline & Compost & 99 & 145 & 115 & 461 & 9.24 & 40.94 & 41.4 & 20.84 \\
\hline & Gypsum & 100 & 145 & 119 & 466 & 9.85 & 41.06 & 42.6 & 21.47 \\
\hline & Compost+ Gypsum & 101 & 147 & 119 & 483 & 10.42 & 41.54 & 43.3 & 22.20 \\
\hline \multicolumn{2}{|r|}{ L.S.D 0.05} & 0.84 & 1.01 & 2.44 & 6.87 & 0.38 & 0.46 & 0.88 & 0.56 \\
\hline \multirow{4}{*}{ 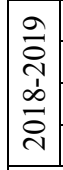 } & Control & 107 & 151 & 122 & 493 & 7.87 & 40.29 & 32.2 & 19.04 \\
\hline & Compost & 110 & 156 & 126 & 528 & 9.65 & 44.49 & 35.4 & 21.78 \\
\hline & Gypsum & 110 & 155 & 127 & 535 & 10.30 & 44.20 & 36.3 & 22.41 \\
\hline & Compost+ Gypsum & 111 & 158 & 129 & 548 & 10.93 & 45.34 & 37.3 & 23.28 \\
\hline & L.S.D 0.05 & 0.92 & 0.99 & 1.82 & 5.08 & 0.27 & 0.42 & 0.85 & 0.68 \\
\hline \multicolumn{10}{|c|}{ Cultivars } \\
\hline \multirow{3}{*}{$\frac{\infty}{1}$} & Shandaweel 1 & 96 & 145 & 108 & 459 & 9.13 & 37.34 & 45.6 & 21.09 \\
\hline & Sids 1 & 99 & 144 & 119 & 468 & 9.06 & 41.66 & 37.6 & 19.82 \\
\hline & Sids 14 & 100 & 145 & 120 & 453 & 9.58 & 40.43 & 42.7 & 21.07 \\
\hline \multicolumn{2}{|r|}{ L.S.D 0.05} & 0.61 & 0.53 & 1.47 & 6.81 & 0.18 & 0.52 & 0.84 & 0.26 \\
\hline \multirow{3}{*}{\begin{tabular}{l|}
$a$ \\
$\frac{a}{0}$ \\
\end{tabular}} & Shandaweel 1 & 108 & 154 & 118 & 532 & 9.84 & 40.43 & 39.3 & 22.78 \\
\hline & Sids 1 & 110 & 156 & 129 & 514 & 9.18 & 45.78 & 31.8 & 20.06 \\
\hline & Sids 14 & 112 & 155 & 130 & 532 & 10.05 & 44.53 & 34.7 & 22.04 \\
\hline & L.S.D 0.05 & 0.67 & 0.77 & 1.11 & 6.81 & 0.21 & 0.54 & 0.70 & 0.43 \\
\hline
\end{tabular}

$\mathrm{I}_{1}: 100 \%$ of field capacity and $\mathrm{I}_{2}: 120 \%$ of field capacity ns: non-significant. * and **: significant at 0.05 and 0.01 levels of probability, respectively.

5- Effect of interaction between irrigation levels and compost or/and gypsum treatments:
Data in Table 3 reveal that the interaction between irrigation levels and compost or/and gypsum treat- 
ments was significant for number of spikes $/ \mathrm{m}^{2}$ and number of kernels/spike in the first season. Meanwhile, it was insignificant for the other traits under study. The highest mean values of kernels number/spike (42.9 and 39.0 kernel) were obtained under $120 \%$ of field capacity and gypsum in the first season and under $120 \%$ of field capacity and compost + gypsum in the second season. The highest mean values of spikes number $/ \mathrm{m}^{2}$ (516 and 570 spike $/ \mathrm{m}^{2}$ ), biological yield (10.98 and 11.67 ton), 1000-kernel weight (43.27 and 47.09 g) and grain yield/fed were obtained under $120 \%$ of field capacity and compost + gypsum treatments in both seasons, Whereas the lowest values of these traits (38.8 and 29.7 kernel), (414 and 473 spike), (6.75 and 6.95 ton), (34.09 and $38.82 \mathrm{~g}$ ) and (16.89 and 17.47 ard.) were obtained under $100 \%$ of field capacity and control treatment in the first and second seasons, respectively.

6- Effect of interaction between irrigation levels and wheat cultivars:

The data in Table 3 clear that the interaction between irrigation levels and wheat cultivars was significant or highly significant for number of spikes and number of kernels/spike in the first season and for days to maturity, biological yield and grain yield in the second season. Shandaweel 1 had the shortest heading duration (95 and 106 day). For days to maturity Sids 1 gave the shortest maturity duration (142 days in the first season), while Sids14 gave the shortest maturity duration (151 days) in the second season. Sids 14 gave the tallest plants with mean values of 122 and $132 \mathrm{~cm}$ and the heaviest biological yield with mean values of (10.20 and 10.98 ton) under $120 \%$ of field capacity treatment in the first and second seasons, respectively. For number of spikes, Sids 1 gave the highest number of spikes (490 spike) in the first season, while Sids 14 gave the highest number of spikes 553 spike in the second season under $120 \%$ of field capacity treatment. Sids 1 gave the heaviest 1000-kernel weight with mean values of (43.69 and $47.63 \mathrm{~g})$ under $120 \%$ of field capacity in the first and second seasons, respectively, while this cultivar gave the lowest mean values of biological yield 8.54 tons in the second season, and grain yield (18.53 and 18.83ard.) in the first and second seasons, respectively, under $100 \%$ of field capacity.Shandaweell gave the highest mean values of grain yield (22.29 and 24.22 ard.) and the greatest mean values of the number of kernels/spike (46.2 and 41.3 kernel), under $120 \%$ of field capacity treatment, in the first and second season, respectively.

The significance of the interactions is a result of the different abilities of the cultivars to adjust their traits to the environment, suggesting the importance of genotype assessment under different environments to identify the best ones for a particular environment. Yassin et al., (2019) reported that the interactions between genotypes and the soil salinity were significant or highly significant for all the studied traits except for plant height in the first season. Attia and El-Araby, (2017) found a significant interaction between salinity levels and wheat cultivars for plant height, biological yield and grain yield. Gadallah et al., (2017) stated that increased the 
salinity levels decreased significantly each of days to heading, plant height, number of spikes, 1000-kernel weight and grain yield. These results are in harmony with those reported by AlNaggar et al., (2015 a) and Ragab and Taha, (2016).

Table 3. Effect of the interaction between irrigation levels and each of compost and gypsum treatments and wheat cultivars for the studied traits in 2017/2018 and 2018/2019 seasons.

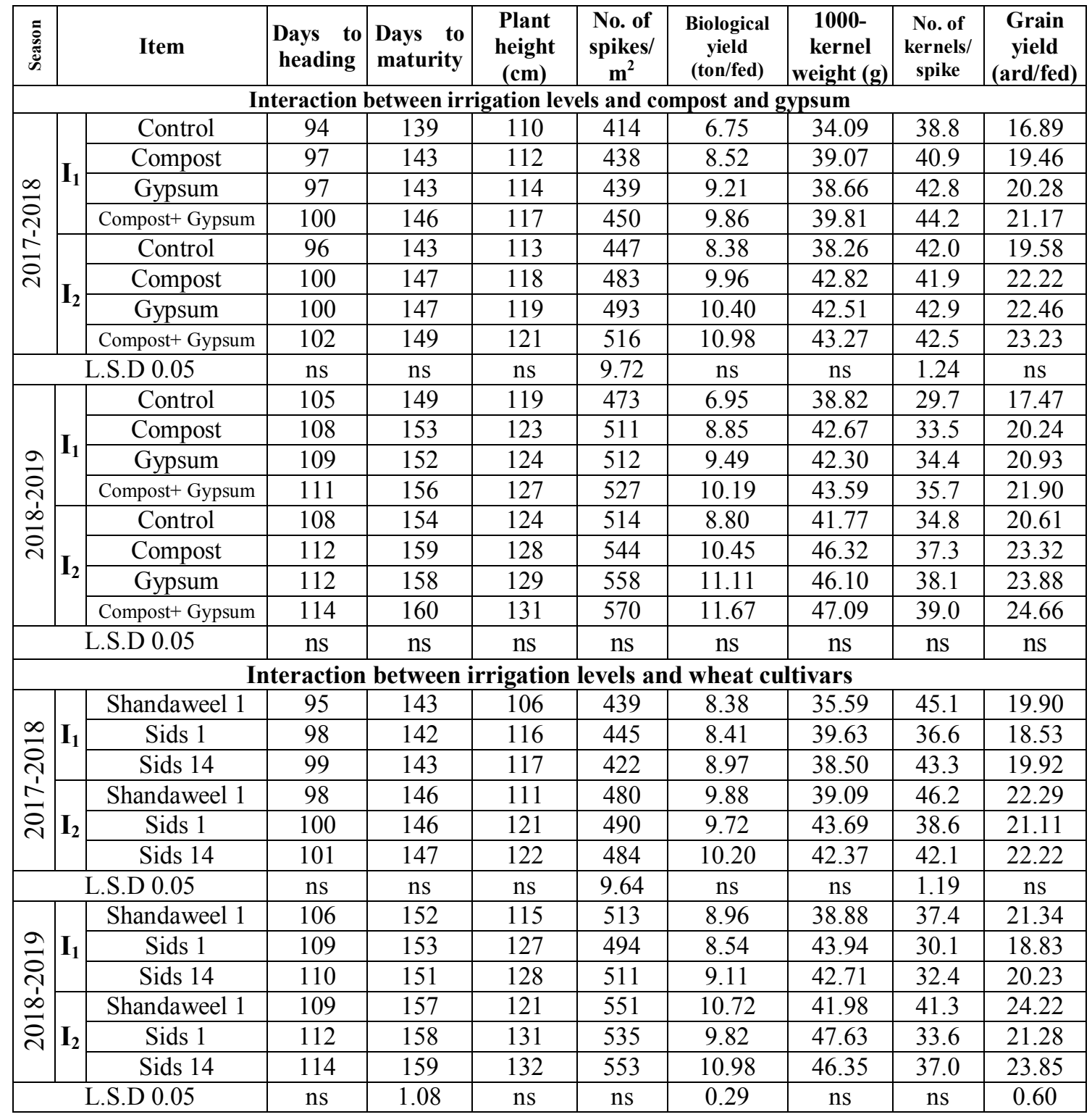

$\mathrm{I}_{2}=120 \%$ of field capacity

$\mathrm{I}_{1}=100 \%$ of field capacity

ns: mean non-significant at $5 \%$ level of probability.

7- Effect of interaction between compost or/and gypsum treatments and wheat cultivars:

The interaction between compost or/and gypsum treatments and wheat cultivars (Table 4) was significant for days to maturity and 1000- kernel weight in the first season and for plant height and 1000-kernel weight in the second season. During the first season, Sids 1 was the earliest for days to maturity (140 day), Shandaweel 1 was the earliest of days to heading (93 day) and the shortest 
cultivar $(106 \mathrm{~cm})$ and it gave the highest mean value of kernels number/spikes (46.8 kernel) and grain yield (22.74 ard.). Sids 14 gave the highest mean value of biological yield (10.79 ton/fed), while Sids 1 gave the highest mean value of spikes number $/ \mathrm{m}^{2}$ (493 spike) and 1000kernel weight $(43.37 \mathrm{~g})$ under combost+gypsum treatment. On the other hand, Sids 1 gave the lowest mean value of biological yield (7.32 ton), number of kernels/spike (36.0 kernel) and grain yield (17.38 ard.) under the control treatment, Sids 14 gave the lowest mean value of the number of spikes (425 spike), while the lowest mean value of 1000-kernel weight was recorded from Shandaweel 1 $(34.43 \mathrm{~g})$ under the same treatment. On the other hand, in the second season, Shandaweel 1 was shortest culti$\operatorname{var}(115 \mathrm{~cm})$ and the earliest for days to heading (105 day) and days to maturity (150 day) and it gave the highest mean values of number of spikes (557 spike), number of kernels/ spikes (41.5 kernel) and grain yield (24.73 ard.) under combost+gypsum treatment, while Sids 14 gave the highest mean value of biological yield (11.33 ton), Sids 1 gave the highest mean value of 1000-kernel weight $(47.79 \mathrm{~g})$ under the same treatment. On the other hand, Sids 1 gave the lowest mean value of the number of spikes (479 spike), biological yield (7.40 ton), number of kernels/spike (29.7 kernel) and grain yield (17.61 ard.) under the control treatment, while the lowest mean value of 1000-kernel weight was recorded from Shandaweel 1 under the same treatment in the first season.

\section{8- Effect of the second order inter- action:}

The interaction between irrigation levels, compost and/or gypsum treatments and wheat cultivars was significant for days to maturity in the first season and for plant height in the second season (Tables 5 and 6). Results indicate that Shandaweel 1 gave the highest mean value of grain yield (23.67 ard/fed.) under $120 \%$ of field capacity and compost + gypsum treatment, while Sids 1 gave the highest mean value of the number of spikes $/ \mathrm{m}^{2}$ (527 spike). Sids 14 gave the highest mean value of biological yield (11.36 ton/fed) in the first season. On the other hand, Shandweel 1 under $120 \%$ of field capacity and combost+gypsum treatment gave the highest mean value of grain yield (26.13 ard/fed.), number of spikes $/ \mathrm{m}^{2}$ (577 spike) and number of kernels/spike (43.3 kernel), while it gave the lowest mean value of 1000 -kernel weight $(39.37 \mathrm{~g})$ under $100 \%$ of field capacity and control treatment in the second seasons. Moreover, Sids 1 had the highest mean value of 1000 kernel weight under $120 \%$ of field capacity and compost + gypsum treatment $(49.47 \mathrm{~g})$, while Sids 14 had the highest mean value of biological yield (12.28 ton/fed) under $100 \%$ of field capacity and control treatment during the second season. 
Table 4. Effect of the interaction between compost and gypsum treatments and wheat cultivars for the studied traits in $2017 / 2018$ and 2018/2019 seasons.

\begin{tabular}{|c|c|c|c|c|c|c|c|c|c|c|}
\hline 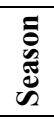 & & Item & $\begin{array}{c}\text { Days to } \\
\text { heading }\end{array}$ & $\begin{array}{l}\text { Days to } \\
\text { maturity }\end{array}$ & $\begin{array}{c}\text { Plant } \\
\text { height } \\
\text { cm. }\end{array}$ & $\begin{array}{c}\begin{array}{c}\text { No. of } \\
\text { spikes/ } \\
\mathrm{m}^{2}\end{array} \\
\end{array}$ & $\begin{array}{c}\text { Biological } \\
\text { yield } \\
\text { (ton } / \text { fed) }\end{array}$ & $\begin{array}{c}1000- \\
\text { kernel } \\
\text { weight }\end{array}$ & $\begin{array}{c}\text { No. of } \\
\text { kernels/ } \\
\text { spike }\end{array}$ & $\begin{array}{c}\text { Grain } \\
\text { yield } \\
\text { (ard/fed) }\end{array}$ \\
\hline \multirow{12}{*}{ 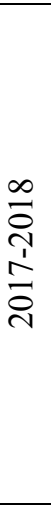 } & \multirow{3}{*}{$\begin{array}{l}\bar{O} \\
\stackrel{0}{0} \\
0\end{array}$} & Shandaweel 1 & 93 & 141 & 106 & 431 & 7.49 & 34.43 & 43.3 & 18.60 \\
\hline & & Sids 1 & 95 & 140 & 113 & 437 & 7.32 & 37.40 & 36.0 & 17.38 \\
\hline & & Sids 14 & 96 & 142 & 116 & 425 & 7.90 & 36.68 & 41.8 & 18.72 \\
\hline & \multirow{3}{*}{ 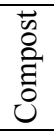 } & Shandaweel 1 & 97 & 145 & 107 & 456 & 9.17 & 38.13 & 45.8 & 21.24 \\
\hline & & Sids 1 & 99 & 145 & 119 & 470 & 8.88 & 42.97 & 36.9 & 20.02 \\
\hline & & Sids 14 & 100 & 145 & 120 & 456 & 9.67 & 41.73 & 41.5 & 21.27 \\
\hline & \multirow{3}{*}{ 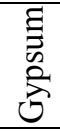 } & Shandaweel 1 & 97 & 145 & 108 & 466 & 9.68 & 37.53 & 46.6 & 21.80 \\
\hline & & Sids 1 & 99 & 144 & 121 & 471 & 9.76 & 42.90 & 38.6 & 20.59 \\
\hline & & Sids 14 & 101 & 145 & 120 & 460 & 9.99 & 41.32 & 43.3 & 21.72 \\
\hline & \multirow{3}{*}{ 喜 } & Shandaweel 1 & 99 & 147 & 112 & 485 & 10.19 & 39.27 & 46.8 & 22.74 \\
\hline & & Sids 1 & 101 & 146 & 122 & 493 & 10.28 & 43.37 & 38.9 & 21.29 \\
\hline & & Sids 14 & 103 & 148 & 123 & 471 & 10.79 & 41.99 & 44.3 & 22.56 \\
\hline \multicolumn{3}{|c|}{ L.S.D 0.05} & ns & 1.07 & ns & $\mathrm{ns}$ & $\mathrm{ns}$ & 1.04 & ns & $\mathrm{ns}$ \\
\hline \multirow{12}{*}{ 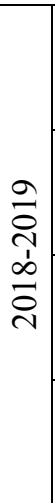 } & \multirow{3}{*}{ 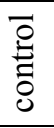 } & Shandaweel 1 & 105 & 150 & 115 & 499 & 7.93 & 37.95 & 35.4 & 19.90 \\
\hline & & Sids 1 & 107 & 152 & 123 & 479 & 7.40 & 41.77 & 29.7 & 17.61 \\
\hline & & Sids 14 & 108 & 152 & 127 & 502 & 8.30 & 41.17 & 31.5 & 19.61 \\
\hline & \multirow{3}{*}{$\begin{array}{l} \\
\text { : } \\
\text { :्ञ } \\
0 \\
0\end{array}$} & Shandaweel 1 & 108 & 155 & 118 & 532 & 9.84 & 41.08 & 39.5 & 22.80 \\
\hline & & Sids 1 & 111 & 157 & 129 & 517 & 9.03 & 46.78 & 31.8 & 20.34 \\
\hline & & Sids 14 & 112 & 156 & 131 & 534 & 10.08 & 45.62 & 34.9 & 22.19 \\
\hline & \multirow{3}{*}{ 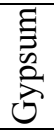 } & Shandaweel 1 & 108 & 155 & 118 & 540 & 10.51 & 40.50 & 41.0 & 23.68 \\
\hline & & Sids 1 & 111 & 155 & 132 & 524 & 9.90 & 46.80 & 32.6 & 20.74 \\
\hline & & Sids 14 & 113 & 155 & 131 & 541 & 10.49 & 45.30 & 35.2 & 22.80 \\
\hline & \multirow{3}{*}{ 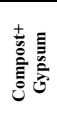 } & Shandaweel 1 & 111 & 157 & 122 & 557 & 11.09 & 42.19 & 41.5 & 24.73 \\
\hline & & Sids 1 & 113 & 159 & 133 & 236 & 10.38 & 47.79 & 33.2 & 21.54 \\
\hline & & Sids 14 & 115 & 158 & 132 & 552 & 11.33 & 46.04 & 37.3 & 23.58 \\
\hline \multicolumn{3}{|c|}{ L.S.D 0.05} & ns & ns & 2.23 & $\mathrm{~ns}$ & $\mathrm{~ns}$ & 1.08 & ns & ns \\
\hline
\end{tabular}

ns: mean non-significant at $5 \%$ level of probability. 
Table 5. Effect of the interaction between irrigation levels, compost and gypsum treatments and the three wheat cultivars for the studied traits in 2017/2018 season.

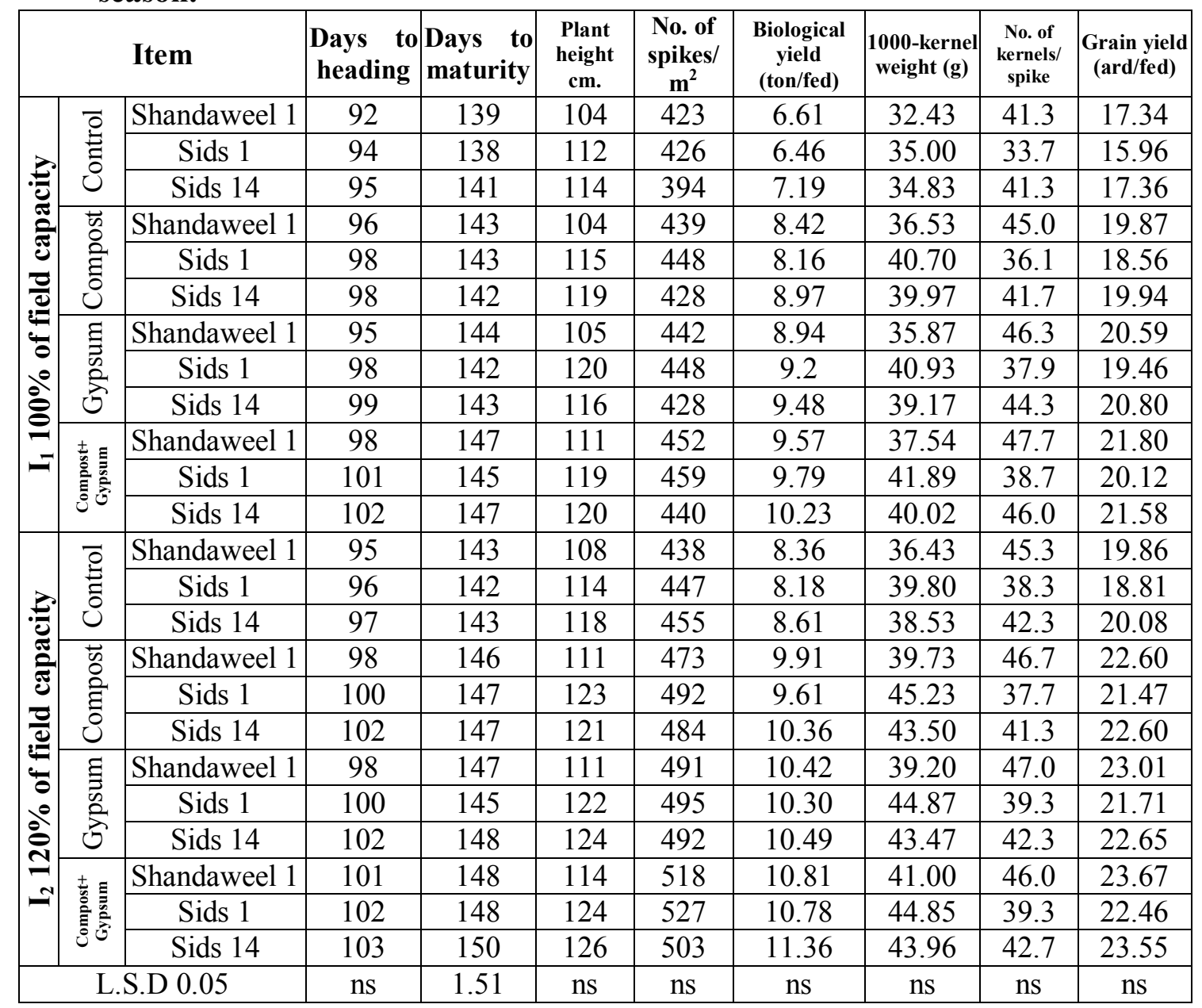

ns: mean non-significant at $5 \%$ level of probability.

\section{Conclusion}

In this study, the influence of sodic and soil salinity on three wheat cultivars and some soil properties was studied. The results explained that the irrigation treatments had a significant or highly significant effect on the three wheat cultivars traits under study in both seasons. Moreover, leaching process and soil amendments application (compost and gypsum) had been applied as soil addition respectively to resisting the sodic salinity effect. The results explain that treatment of compost or gypsum effected significantly in all the studied traits in both seasons as compared to control treatment under conditions.
Furthermore, the obtained results from this study indicated that all the used amendments either, singly or in combination showed a pronounced decreased in $\mathrm{EC}, \mathrm{pH}$, sodium, and concentration compared with control. The results show that combined treatments more efficient than a single one. Increase the rate of gypsum used leads to an increase in decrease salinity as well as sodicity. Thence, the soil properties enhanced which led it to positive effect on crop production. 
Table 6. Effect of the interaction between irrigation levels, compost and gypsum treatments and the three wheat cultivars for the studied traits in 2018/2019 season.

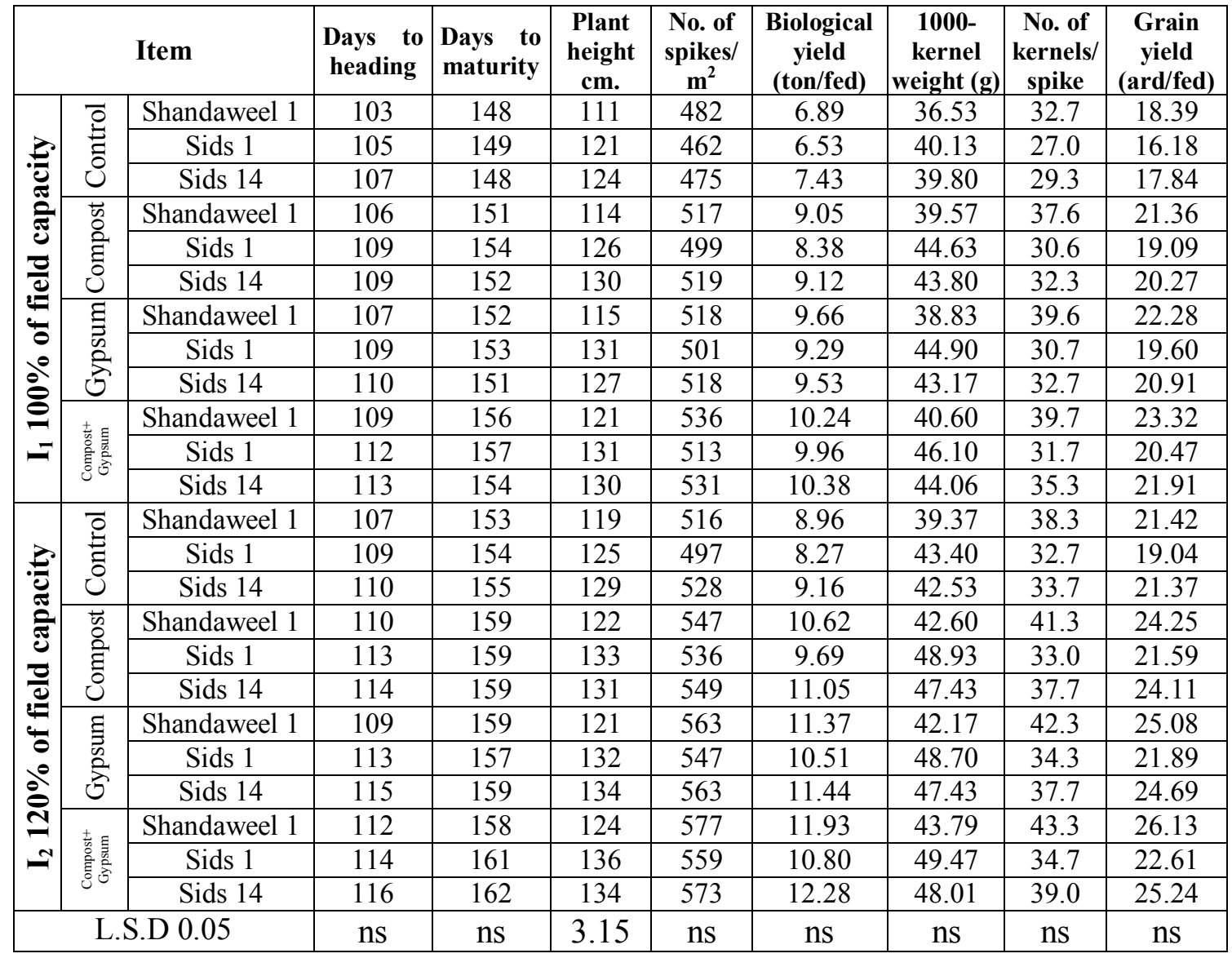

ns: mean non-significant at $5 \%$ level of probability.

In general, we found that using compost and/or gypsum and irrigation by $120 \%$ of field capacity to leach the salty soil were effective in improve soil properties and increase grain yield of wheat cultivars.

\section{References}

Abdelaal, A.A.K., O.I. Reda, H.M. Yaser, S.M. Esmail and A. EL Sabagh, (2018). Anatomical, Biochemical and Physiological Changes in Some Egyptian Wheat Cultivars Inoculated with Puccinia graminif. sp. triticif. sp. tritici f. sp. tritici. Fresen. Env. Bull. 27, 296305.

Abdel-Fattah M. K. and A. M. A. Merwad (2016). Approach for Reclamation and Improving Fertility of
Saline-Sodic Soils. Egypt. J. Soil Sci. Vol. 56, No.4, pp.573-588.

Abdel-Fattah, M.K. (2011). Some Biological and Chemical Methods for Salt Affected Soils Reclamation. Ph.D. Thesis, Faculty. of Agric. Zagazig University, Egypt.

Abdel-Fattah, M.K. (2015). Potential Use of Halophytes in Combination with Gypsum to Reclaim and Restore Saline-Sodic Soils in Egypt, Malaysian J. of Soil Sci., 19: 131139.

Acevedo, E., H. Harris, and P.J. M. Cooper, (1991). Crop architecture and water use efficiency in Mediterranean environments. In H. Harris, P.J.M. Cooper and M. Pala, eds. Soil and Crop Management for Improved Water Use Efficiency in 
Rainfed Areas, p.106-118. ICARDA.

Al-Naggar, A.M.M., S.R.S. Sabry, M.M.M. Atta and O.M. Abd ElAleem, (2015a). Effects of salinity on performance, heritability, selection gain and correlations in wheat (Triticum aestivumL.) Doubled Haploids. Sci. Agri. 10 (2), 70-83.

Al-Naggar, A.M.M., S.R.S. Sabry, M.M.M. Atta and O.M. Abd ElAleem, (2015b). Field screening of wheat (Triticum aestivum L.) genotypes for salinity tolerance at three locations in Egypt. J. Agric. Ecology Res. Intern. (JAERI). 4 (3), 88104.

Ashraf, M. and P.J.C. Harris, (2005). Abiotic Stresses: Plant Resistance through Breeding and Molecular Approaches. Food Products Press, an imprint of The Haworth Press, Inc., Binghamton, New York, USA, 3-15.

Attia M. G. and A. A. M. El-Araby (2017). Response of Some Egyptian Wheat (Triticum aestivum L.) Genotypes to Salinity Stress J. Adv. Agric. Res. (Fac. Agric. Saba Basha), Vol. 22 (2), 244-257.

Barutcular, C., A. EL Sabagh, M. Koç and D. Ratnasekera, (2017). Relationships between grain yield and physiological traits of durum wheat varieties under drought and high temperature stress in Mediterranean conditions. Fresen. Env. Bull. 26, 4282- 4291.

Black, C.A. (1965). Methods of soil analysis. Part I, American Society of Agronomy. Madison, Wisconsin, USA. 1572 p.

Borlu, H.O, V. Celiktas, S. Duzenli, A. Hossain and A. EL Sabagh, (2018). Germination and early seedling growth of five durum wheat cultivars (Triticum durum desf.) is affected by different levels of salin- ity. Fresen. Env. Bull. 27, 77467757.

Brady N.C. and R.R. Weil (2005). The nature and properties of soils. 13thEdition. Macmillan Publishing Company, New York, 279- 313.

Çelik, H., A.V. Katkat, B.B. Aýk and M. A. Turan (2008). Effects of soil application of humus on dry weight and mineral nutrients uptake of maize under calcareous soil conditions. Archives of Agron. Soil Sci., 54, 605-614.

Chinnusamy, V., A. Jagendorf and J.K. Zhu (2005). Understanding and improving salt tolerance in plants. Crop Sci. 45(2), 437-448.

Dura, S.A.M., M.A. Duwayriand and M.M. Nachit (2011). Effects of Different Salinity Levels on Growth, Yield and Physiology on Durum Wheat (Triticum turgidum var. durum). Jordan J. Agric. Sci., 7(3) : 518-527.

El-Hendawy, S.E., Y.Hu, G.M. Yakout, A.M. Awad, S.E. Hafiz and U. Schmidhalter (2005). Evaluating salt tolerance of wheat genotypes using multiple parameters. Eur. J. Agron. 22, 243-253.

FAO/LPNWS (Land and Plant Nutrition Management Service). (2018). The Environmental and Physiological Nature of Salinity. http://plantstress.com/Articles/salin ity_i/salinity_i.htm. (Accessed on 24 August 2018).

Feizi, M, M. Hajabbasi, B. Mostafazadeh-Fard (2010). Saline irrigation water management strategies for better yield of safflower (Carthamus tinctorius L.) in an arid region. Aust. J. Crop Sci. 2010; 4:408-414.

Gadallah A. Maha, Milad I. Sanaa, Y. M. Mabrook, Abo Yossef Y. Amira, and M. A. Gouda (2017). Evaluation of Some Egyptian Bread Wheat (Triticum aestivum) Culti- 
vars under Salinity Stress. Alex. Sci. Exch. J, Vol.38, No. 2602. 259-270.

Gee, G.W. and D. Orr, (1994). Particle size analysis. In methods of soil analysis part 4. Physical methods. Soil science Amer. Book Series 5. Edited by Dome, J.H. and Topp, G.C. SSSA Madison WI.2002:255293.

Genc, Y., GK Mcdonald and M Tester (2007). Reassessment of tissue $\mathrm{Na}+$ concentration as a criterion for salinity tolerance in bread wheat. Plant, Cell Env., 30: 1486-1498.

Gomez, K.A. and A.A. Gomez, (1984). Statistical procedures for agricultural research $\left(2^{\text {nd }}\right.$ ed. $)$. John wiley and sons, New York, 680p.

Hesse, P.R. (1971). A textbook on soil analysis. John Murray, London.

Huang, S., W. Spielmeyer, E. S. Lagudah and R. Munns (2008). Comparative mapping of HKT genes in wheat, barley, and rice, key determinants of transport and salt tolerance. J. Exp. Bot., 59: 927-937.

Jackson M. (1973). Soil chemical analysis, Prentice-Hall, Inc., Englewood Cliffs, N. J.

Jahan, M.A.H.S., A. Hossain, J.A. Teixeira da Silva, A. EL Sabagh, M.H. Rashid and C. Barutçular, (2019). Effect of Naphthaleneacetic Acid on Root and Plant Growth and Yield of Ten Irrigated Wheat Genotypes. Pak. J. Bot., 51(2): 451- 459.

Manzoor, A., N. Hussain, M. Salim and B.H. Niazi. (2001). Use of chemical amendments for reclamation of saline-sodic soils. Int. J. Agri. Biol. 3(3): 305-307.

Nelson, D.W and L.E Somners, (1982). Total carbon and organic matter. In Page, AL., Miller, R.H., Keenu, D.R (eds). Methods of soil analysis. Part $22^{\text {nd }}$ edn. Agron. Mono- graph NO 9 USA and SSSA Madison, 1:539-579.

Ouhaddach M., H. ElYacoubi, A. Douaik and A. Rochdi. (2018). MorphoPhysiological and Biochemical Responses to Salt Stress in Wheat (Triticum aestivum L.) at the Heading Stage. J. Mater. Env. Sci., 2018, Vol. 9, Issue 6, 1899-1907.

Palm, C. A., K.E. Giller, P.L. Mafongoya, and M. J. Swift (2001). Management of organic matter in the tropics: translating theory into practice. Nutr. Cycle Agro. Ecosystem, 61, 63-75.

Ragab, Kh. E. and N.I. Taha (2016). Evaluation of nine Egyptian bread wheat cultivars for salt tolerance at seedling and adult-plant stage. J. Plant Prod., Mansoura Univ. 7(2), 147-159.

Rengasamy, P. (2010). Soil processes affecting crop production in salt affected soils. Functional Plant Biology. 37, 255-263.

Shahzad, A., M. Iqbal, M. Asif, A.H. Hirani andA. Goyal (2013). Growing wheat on saline lands: Can a dream come true? Aus. J. of Crop Sci.. 7, 515-524.

Siyal, A.A., A.G. Siyal, and Z.A. Abro. (2002). Salt affected soils their identification and reclamation. Pak. J. of App. Sci. 2(5): 537-540.

Sorour, S. GH., M.A. Aiad, A.A. Ahmed, M.I.A. Henash, E.M. Metwaly, H. Alharby, A. Bamagoos, A. Hossain, C. Barutcular, H. Saneoka and A. Elsabagh (2019). Yield of wheat is increased through improving the chemical properties, nutrient availability and water productivity of salt affected soils in the north delta of Egypt. Applied eco. and Env. Res. 17(4): 82918306.

Turki, N, M. Harrabi and K. Okuno (2012). Effect of salinity on grain yield and quality of wheat and ge- 
netic relationships among durum and common wheat. J. Arid Land Studies. 22, 311-314.

Türkmen, O., A. Dursun, M. Turan and C. Erdinc (2004). Calcium and humic acid affect seed germination, growth and nutrient content of tomato (Lycopersicon esculentum L.) seedlings under saline soil conditions. ActaHorticul. Scandinavica B., 54, 168-174.
US Salinity Laboratory (1954). Diagnosis and Improvement of Saline and Alkaline Soils. Department of Agriculture, Handbook No. 60, p. 160. Yassin M., Fara A. Sahar, A. Hossain, H. Saneoka andA. El Sabagh (2019). Assessment of salinity tolerance bread wheat genotypes: using stress tolerance index. Fresenius Env. Bulletin. Vo. 28 - No. 5/2019 pages 4199-4217. 
تأثير استخدام الكمبوست والجبس الزراعي على المحصول ومساهماته لثلاثة أصناف من قمح

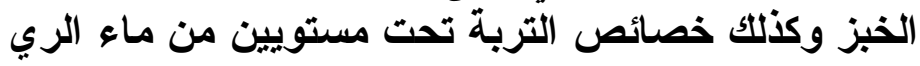

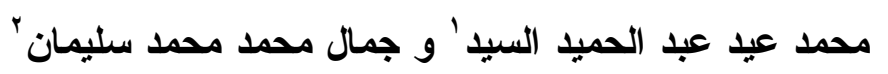

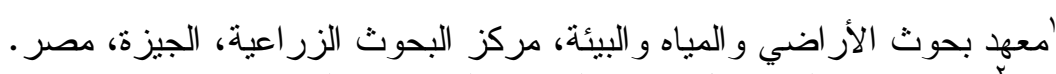

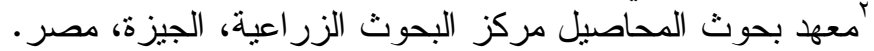

تؤثر الأر اضي الصودية الملحية في إنتاجية المحاصيل، وبالتالي فإن لاستخدام العديد مسن

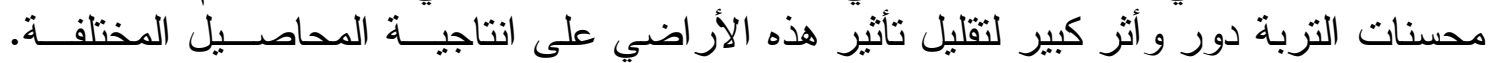

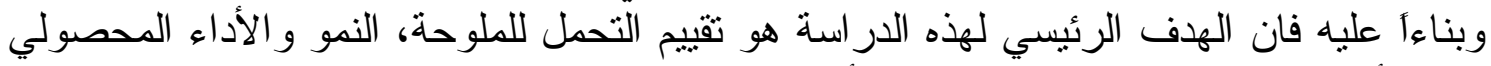

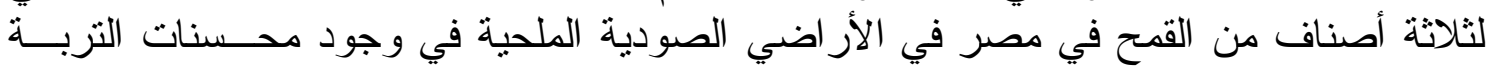

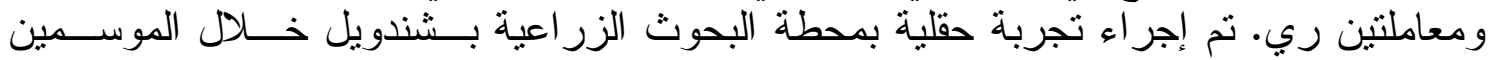

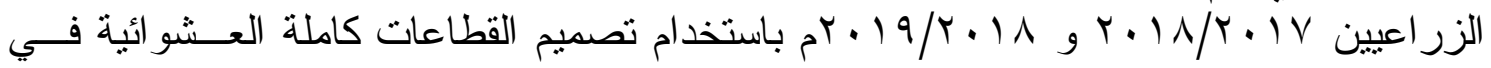

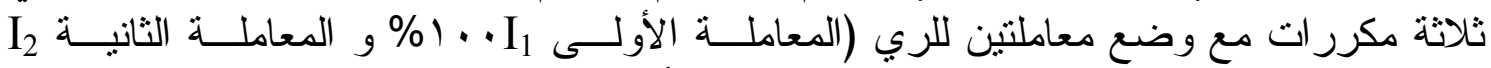

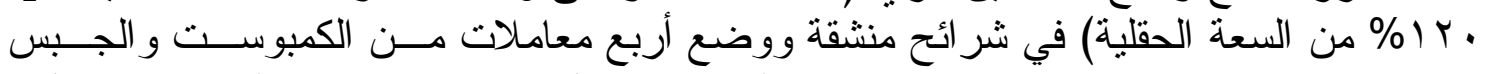

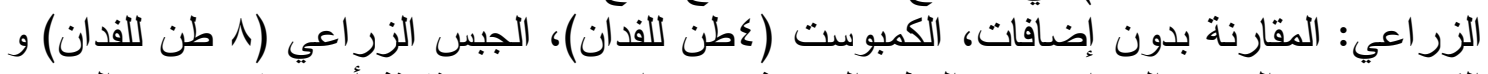

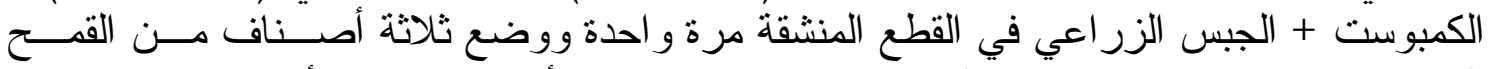

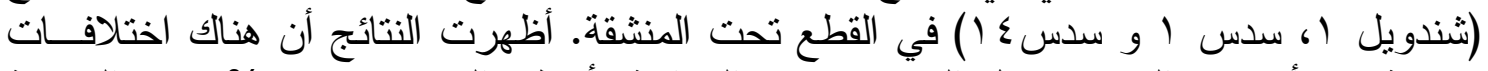

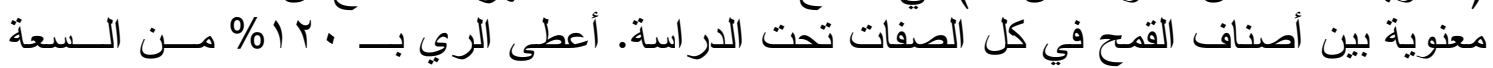

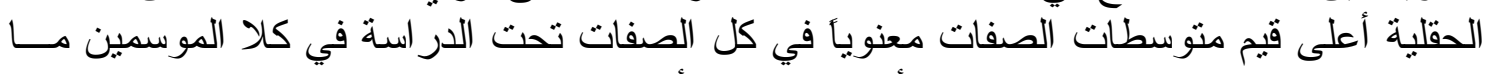

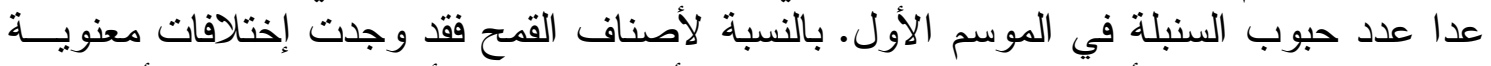

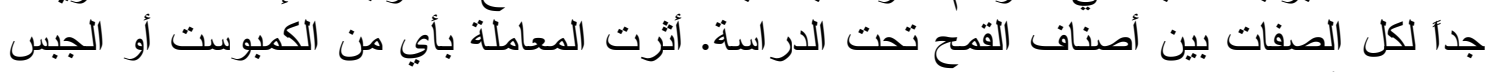

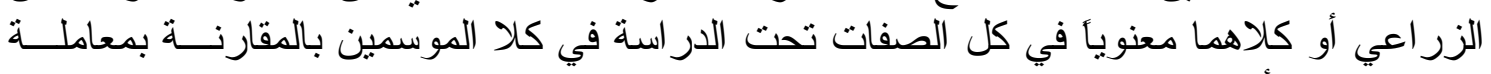

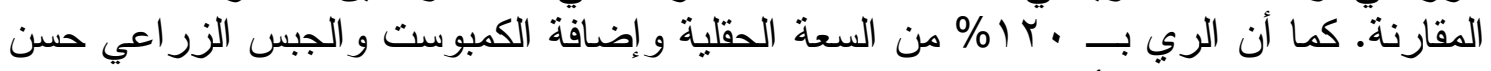
خو اص التربة وقلل من تأثير الملحية. 